\title{
Komposisi Jenis Ikan di Perairan Pantai Teluk Saleh, Nusa Tenggara Barat (NTB) dan Tanimbar Utara, Maluku Tenggara
}

\author{
Composition of fishes in Saleh Bay, Nusa Tenggara Barat (NTB) and North Tanimbar \\ Maluku Tenggara
}

\section{Langkosono}

UPT Loka Pengembangan Bio Industri Laut, Pusat Penelitian Oseanografi-LIPI Mataram, Dusun Teluk Kodek Kecamatan Pemenang Lombok Barat, NTB.

\begin{abstract}
Study of the fish diversity in Saleh Bay, West Nusa Tenggara (NTB) has been carried out in August 2000, and in North Tanimbar, Maluku Tenggara during November to December 2002. The fishes collecting in Saleh Bay using gillnet, beach seine, angling, and light fishing while in North Tanimbar by beach seine. A total specimens which collected from Saleh Bay were 576 samples, consist of 108 species from 29 families while in North Tanimbar were found 2763 specimens, representing 61 species from 28 families.
\end{abstract}

Key words: fish diversity, Saleh Bay, North Tanimbar

Diterima: 3 Januari 2003, disetujui: 17 Juni 2003

\section{Pendahuluan}

Tanimbar Utara terletak di bagian utara Pulau Yamdena, Maluku Tenggara. Wilayah pesisir daerah ini kebanyakan jauh dengan pusat kota dan pemukiman penduduk sehingga perairannya masih kaya dengan berbagai jenis biota. Kondisi tersebut juga ditunjang oleh komposisi ekosistemnya yang lengkap, seperti hutan bakau (mangrove), padang lamun (seagrass) dan terumbu karang (coral reef) (Langkosono, 1991; Langkosono dan Wenno, 2000). Selain itu dijumpai juga pantai berbatu, pantai berpasir dan pantai berlumpur serta berlanjut dengan bukit karang pada wilayah pesisirnya. Di sekitarnya dikelilingi oleh laut dalam dan laut dangkal, keadaan serupa dijumpai pula pada perairan pantai Teluk Saleh, Nusa Tenggara Barat (NTB). Namun pada perairan ini ekosistemnya sebagian mengalami kerusakan fisik diduga akibat penangkapan ikan menggunakan cara yang bersifat merusak (Rencana Strategis Pengelolaan Pesisir dan Laut NTB, 1998).
Kegiatan perikanan yang menonjol di kedua perairan yang disebut, adalah penangkapan ikan di laut. Hasil tangkapan para nelayan jumlah berfluktuasi, pada musim tertentu hasil tangkapannya banyak dan harganya murah, sedangkan pada waktu lain hasil tangkapan hanya sedikit sehingga harga relatif mahal. Namun demikian kontribusi sektor perikanan terhadap pendapatan daerah cukup besar, terutama dalam penyediaan kebutuhan protein hewani untuk mencerdaskan kehidupan bangsa. Oleh karena ini perlu dikaji tentang komposisi jenis ikan yang tertangkap di kedua perairan tersebut, sehingga strategi pengembangan perairan tersebut di masa yang akan datang dapat ditetapkan.

Tujuan penelitian ini adalah untuk mengetahui distribusi dan struktur komunitas ikan di kedua perariran tersebut. Hasil penelitian ini diharapkan dapat menjadi dasar acuan untuk pengelolaan perikanan maupun konservasi yang bernilai niaga penting. Dengan demikian Pemerintah dalam mengembangkan sektor perikanan di masa yang akan datang, diharapkan mengacu pada usaha meningkatkan kualitas hidup para nelayan wilayah pesisir. 


\section{Metode Penelitian}

Pemantauan pada perairan Kecamatan Tanimbar Utara dilakukan pada bulan Nopember dan Desember 2002 pada tujuh Stasiun. Stasiun (S) tersebut, meliputi Pulau Fordate (S1), Karangmetirotan (S2), Pulau Yamdena bagian utara (S3), Pulau Famusan (S4), Pulau Wermatan (S5), Pulau Maru (S6) dan Pulau Namwaan (S7). Sedangkan penelitian pada perairan pantai Teluk Saleh dilakukan pada bulan Agustus tahun 2000. Stasiun (S) pemantauan pada perairan tersebut meliputi, Labuan Terata (S1), Teluk Santong (S2), Dusun Wajo (S3), Labuan Juntal (S4).

Contoh ikan pada perairan Tanimbar Utara berasal dari hasil tangkapan jaring tarik (beach seine), sedangkan pada perairan pantai Teluk Saleh berasal dari hasil tangkapan jaring insang (gillnet), jaring tarik (beach seine) bagan (lighting fish) dan pancing (angling). Ikan yang diperoleh dikumpulkan, dihitung menurut jenis, diukur panjang berat dan diidentifikasi. Identifikasi ikan dilakukan menurut cara Weber and De Beaufort (1936), Munro (1967), Sato (1978), Allen and Talbot (1985), Randall and Heemstra (1991) serta Kuiter (1992). Analisis untuk menentukan keragaman ikan dilakukan menurut model Shannon Weaver (dalam: Odum 1971), sedangkan kemerataan jenis dilakukan menurut cara Pielow (1976).

Derajat penting jenis-jenis ikan yang dominan dalam komunitas ditentukan dengan menghitung Indeks biologi menurut cara Warfell and Merriman (1944 dalam Hutomo dan Djamali (1980). Cara ini diterangkan secara mendalam mengenai kepadatan ikanikan di pantai Pulau Burung dan Muara Sungai Karang (Hutomo dan Martosewojo, 1977; Hutomo 1978).

\section{Hasil dan Pembahasan}

\section{Hasil koleksi ikan di perairan pantai Tanimbar Utara}

Pada perairan ini diperoleh hasil tangkapan ikan sebanyak 2763 spesimen, yang terdiri dari 61 jenis yang mewakili 28 suku. Pada Stasiun 1 (S1) jumlah hasil tangkapan yang diperoleh sebanyak 305 ekor yang terdiri dari 27 jenis yang mewakili 17 suku. Berdasarkan jumlah individu dari jenis yang menonjol (banyak tertangkap), yaitu Pranesus pinguis dari suku Atherinidae menempati urutan pertama dengan hasil tangkapan 145 ekor (47,5\%). Jumlah individu jenis-jenis lainnya yang diperoleh berkisar antara 0,3 - 5,5\%.

Pada Stasiun 2 (S2) jumlah hasil tangkapan yang diperoleh sebanyak 352 ekor yang terdiri dari 23 jenis yang mewakili 14 suku. Berdasarkan jumlah individu dari jenis yang menonjol (banyak tertangkap), yaitu $S$. canaliculatus dari suku Siganidae yang menempati urutan pertama dengan hasil tangkapan 81 ekor $(23,0 \%)$. Jumlah individu jenis-jenis lainnya berkisar antara 0,3 - 19,0\%.

Pada Stasiun 3 (S3) jumlah hasil tangkapan yang diperoleh sebanyak 906 ekor yang terdiri dari 36 jenis yang mewakili 20 suku. Berdasarkan jumlah individu dari jenis yang menonjol (banyak tertangkap), yaitu sama jenisnya dengan yang ditemukan pada S1, yaitu Pranesus pinguis yang menempati urutan pertama dengan hasil tangkapan 450 ekor $(49,7 \%)$. Jumlah individu jenis-jenis lainnya yang diperoleh berkisar antara 0,1 $8,2 \%$.

Pada Stasiun 4 (S4) jumlah hasil tangkapan yang diperoleh sebanyak 277 ekor yang terdiri dari 25 jenis yang mewakili 14 suku. Berdasarkan jumlah individu dari jenisjenis lainnya yang menonjol (banyak tertangkap), yaitu Stolephorus indicus dari suku Engraulidae menempati urutan pertama dengan hasil tangkapan 120 ekor (43,3\%). Jumlah individu jenis-jenis lainnya yang diperoleh berkisar antara 0,4 - 12,6\%.

Pada Stasiun 5 (S5) jumlah hasil tangkapan yang diperoleh sebanyak 455 ekor yang terdiri dari 24 jenis yang mewakili 17 suku. Berdasarkan jumlah individu yang menonjol (banyak tertangkap), yaitu Apogon leptacanthus dari suku Apogonidae yang menempati urutan pertama dengan jumlah hasil tangkapan 80 ekor $(17,6 \%)$. Jumlah individu jenis ikan lainnya yang diperoleh berkisar antara $0,2-16,5 \%$.

Pada Stasiun 6 (S6) jumlah hasil tangkapan yang diperoleh sebanyak 210 ekor 
yang terdiri dari 15 jenis yang mewakili 8 suku. Berdasarkan jumlah individu yang menonjol (banyak tertangkap), yaitu jenis Siganus guttatus dari suku Siganidae dengan jumlah hasil tangkapan sebanyak 57 ekor $(27,1 \%)$. Jumlah individu jenis-jenis lainnya yang diperoleh berkisar antara 0,5 - 18,8\%.

Pada Stasiun 7 (S7) jumlah hasil tangkapan yang diperoleh sebanyak 252 ekor yang terdiri dari 22 jenis yang mewakili 12 suku. Berdasarkan jumlah individu dari jenis yang menonjol (banyak tertangkap), adalah $S$. vermiculatus dari suku Siganidae dengan jumlah hasil tangkapan yang diperoleh sebesar 65 ekor $(25,8 \%)$. Jumlah individu jenis-jenis lainnya berkisar antara $0,4-17,1 \%$.

\section{Hasil koleksi ikan di perairan pantai Teluk Saleh, NTB}

Dalam penelitian ini berhasil dikoleksi sebanyak 576 spesimen ikan, terdiri dari 108 jenis yang mewakili 29 suku. Ikan yang tertangkap pada Stasiun 1 (S1) sebanyak 152 spesimen $(14,83 \%)$, terdiri dari 60 spesies yang mewakili 22 suku. Ada dua spesies ikan yang dominan pada lokasi ini, yaitu Sardinella Lemuru $(9,21 \%)$ dari suku Clupeidae dan Gerres kapas $(4,61 \%)$ dari suku Gerridae, sedangkan jenis ikan lainnya yang berhasil tertangkap berkisar antara 0,66-3,29\% .

Pada Stasiun 2 (S2) terkumpul 248 spesimen $(24,20 \%)$, terdiri dari 74 spesies dari 24 suku. Terdapat tiga jenis yang dominan pada Stasiun ini, yaitu S. lemuru $(20,16 \%)$ dari suku Clupeidae, Nemipterus virgatus dan $N$. mesoprion masing-masing 8,47\% dan 7,66\% dari suku Nemipteridae, sedangkan jenis ikan lainnya berkisar antara $0,40-6,85 \%$.

Pada Stasiun 3 (S3) terkumpul 79 spesimen $(7,71 \%)$, terdiri dari 36 spesies ikan yang mewakili 14 suku. Jenis ikan yang paling dominan adalah $S$. lemuru $(8,86 \%)$ dari suku Clupeidae dan Upeneus. sulphureus (6,33\%) dari suku Mullidae, sedangkan jenis lainnya berkisar antara 1,23-4,94\%.

Pada Stasiun 4 (S4) terkumpul 95 spesimen $(9,27 \%)$, terdiri dari 42 spesies yang mewakili 20 suku. Jenis ikan yang paling banyak dijumpai adalah Sardinella lemuru $(21,05 \%)$ dari suku Clupeidae dan $N$. virgatus
$(9,47 \%)$ dari suku Nemipteridae, jenis iakn lainnya berkisar antara 1,05-5,26\%.

Jenis ikan yang dominan dijumpai pada perairan Tanimbar Utara dan Teluk saleh berbeda, baik jumlah maupun komposisinya. Namun jenis ikan lainnya yang tidak dominan rata-rata mempunyai sebaran yang sama. Perbedaan dan kesamaan ini dapat dipengaruhi oleh beberapa faktor antara lain jenis alat tangkap, lokasi, musim dan kualitas lingkungan perairan. Secara keseluruhan hasil yang dijumpai pada penelitian ini hampir sama denga yang dilaporkan oleh Ayodhyoa (1981).

Komunitas jenis ikan dominan pada kedua perairan terbatas dan secara teoritis sama dengan hukum ekologi bahwa dalam suatu komunitas biasanya terdiri dari banyak jenis, tetapi beberapa jenis saja yang merupakan kelompok predominan (Odum, 1971). Hasil serupa juga diperkuat oleh Merriman and Warfell (1944 dalam: Hutomo 1978) di Block Island Sound, Richards (1963) di Long Island Sound, Oviat and Nixon (1973) di Teluk Narragansett. Di perairan Indonesia, fenomena yang sama juga dilaporkan oleh Hutomo dan Martosewojo (1977) pada komunitas ikan di bagian Barat Pulau Burung. Kondisi tersebut menurut Gunther (1935 dalam: Hutomo, 1978), disebabkan oleh persaingan untuk mendapatkan makanan, buaya, predator, dan faktor biotanya sendiri. Di samping itu, juga disebabkan oleh kondisi lingkungan perairan, seperti suhu, salinitas, arus dan kecerahan.

Hasil tangkapan Genisa (1990) menggunakan jaring pantai di perairan Teluk Tering Pulau Batam, sebagai peringkat pertama adalah jenis Gerres macrosoma dari suku Gerridae. Di lain pihak Hutomo (1985) dalam penelitiannya di Teluk Banten mendapatkan Gerres oyena dari suku Gerridae sebagai peringkat pertama, sedangkan Setyono et al. (1991) adalah Pranesus pinguis pada peringkat pertama. Hasil penelitian di perairan Tanimbar Utara dan Teluk Saleh memperlihatkan terdapat jenis-jenis ikan terpenting dalam komunitas hampir sama dengan yang dikemukakan oleh para ahli yang disebut di atas. 


\section{Struktur indeks komunitas ikan di perairan pantai Tanimbar Utara dan Teluk Saleh}

Hasil analisis jenis ikan pada perairan pantai Tanimbar Utara (Tabel 1) menunjukkan indeks keanekaragaman jenis $(\mathrm{H})$ berkisar antara 0,9211-1,0727 (rata-rata 0,9959), indeks kemerataan jenis berkisar antara 0,59190,8602 (rata-rata 0,7263), sedangkan indeks kekayaan jenis berkisar antara 6,0288-11,8359 (rata-rata 9,2790). Pada Tabel terlihat pula bahwa hasil pada S1 sampai S7 hampir sama, sedangkan indeks kekayaan jenis terbesar terlihat pada S3 dan S1, namun keanekaragaman jenis dan kemerataan jenis ikan lebih rendah
Hasil analisis jenis ikan pada perairan pantai Teluk Saleh, NTB (Tabel 2) memperlihatkan indeks keanekaragaman jenis (H) dari kempat Stasiun yang dipantau, yaitu berkisar antara 1,3151 - 1,6759 (rata-rata 1,4853 , dengan Indeks kemerataan jenis (I) berkisar antara 0,7973 - 0,9323 (rata-rata 0 , 8774) sedangkan Indeks kekayaan jenis (d) berkisar antara 18,3390 - 30,4865 (rata-rata 24,1497). Hasil penelitian juga menunjukkan bahwa S1 dan S4 memiliki keanekaragaman dan kekayaan jenis ikan yang lebih tinggi dibandingkan S2 dan S3. Namun kemerataan jenis pada S1 lebih rendah dibandingkan S2, S3 dan S4. Hal ini mungkin disebabkan karena kelimpahan individu dan jenis yang lebih tinggi pada S1.

Tabel 1. Indeks keanekaragaman jenis (H), kemerataan jenis (I), kekayaan jenis (d), dan kelimpahan jenis ikan di perairan Tanimbar Utara.

\begin{tabular}{ccccccc}
\hline \hline \multirow{2}{*}{ Stasiun } & \multicolumn{7}{c}{ Kelimpahan } & J & Jenis & Suku & Spesimen \\
\cline { 2 - 7 } & $\mathbf{H}$ & 0,6544 & 10,8683 & 28 & 17 & 305 \\
\hline \hline 1 & 0,9471 & 0,7743 & 8,6393 & 23 & 14 & 352 \\
2 & 1,0543 & 0,5919 & 11,8359 & 36 & 20 & 906 \\
3 & 0,9211 & 0,6614 & 9,8260 & 25 & 14 & 277 \\
4 & 0,9246 & 0,7674 & 9,0100 & 25 & 17 & 461 \\
5 & 1,0727 & 0,8602 & 6,0288 & 15 & 8 & 210 \\
6 & 1,0117 & 0,7744 & 8,7449 & 22 & 12 & 252 \\
7 & 1,0396 & $\mathbf{0 , 7 2 6 3}$ & $\mathbf{9 , 2 7 9 0}$ & $\mathbf{2 5}$ & $\mathbf{1 5}$ & $\mathbf{3 9 5}$ \\
\hline \hline Rata-rata & $\mathbf{0 , 9 9 5 9}$ & $\mathbf{0 , 7 9 0}$
\end{tabular}

Tabel 2. Indeks keanekaragaman jenis (H), kemerataan jenis (I), kekayaan jenis (d), dan kelimpahan jenis ikan di perairan Teluk Saleh, NTB.

\begin{tabular}{ccccccc}
\hline \hline \multirow{2}{*}{ Stasiun } & \multicolumn{7}{c}{ Kelimpahan } \\
\cline { 2 - 7 } & $\mathbf{H}$ & $\mathbf{I}$ & $\mathbf{d}$ & Jenis & Suku & Spesimen \\
\hline \hline 1 & 1,4903 & 0,7973 & 30,4865 & 74 & 24 & 248 \\
2 & 1,3890 & 0,8557 & 20,7312 & 42 & 20 & 95 \\
3 & 1,4179 & 0,9046 & 18,3390 & 36 & 14 & 81 \\
4 & 1,6579 & 0,9323 & 27,0419 & 60 & 22 & 152 \\
\hline \hline Rata-rata & $\mathbf{1 , 4 8 5 3}$ & $\mathbf{0 , 8 7 7 4}$ & $\mathbf{2 4 , 1 4 9 7}$ & $\mathbf{5 3}$ & $\mathbf{2 0}$ & $\mathbf{1 4 4}$ \\
\hline \hline
\end{tabular}

Hasil analisis struktur indeks jenis ikan menunjukkan bahwa perairan pantai Teluk Saleh memiliki keanekaragaman, kemerataan dan indeks kekayaan jenis yang lebih tinggi dibandingkan dengan perairan Tanimbar Utara. Hal ini mungkin disebabkan oleh teknik penangkapan, alat tangkap, musim, kedalaman dan kondisi lingkungan perairan yang berbeda. Selain itu perairan Teluk Saleh yang relatiflebih besar dan luas, dan terdapat muara sungai yang membuat salinitas air lebih rendah. Indikator lain adalah ditemukannya ikan bandeng (Chanos chanos) yang biasa hidup diperairan dengan salinitas rendah, 
dan jenis ikan ini tidak pernah dijumpai di perairan Tanimbar Utara. Perairan pantai Tanimbar Utara terdiri dari pulau-pulau kecil yang dikelilingi oleh laut dangkal, laut dalam dan tidak ada sungai sehingga kondisi lautnya bersifat oseanik.

Keanekaragaman, kemerataan dan kekayaan jenis ikan yang di peroleh dalam penelitian ini lebih tinggi dibandingkan dengan yang dilaporkan oleh Genisa (1991) di Muara Sungai Karang Bengawan Solo dan Hutomo dan Djamali (1980) di Padang Lamun, pantai Selatan gugus Pulau Pari. Menurut Liyod dan Ghelardi (1964), salah satu faktor yang berpengaruh pada tinggi rendahnya keanekaragaman jenis ikan adalah kualitas lingkungan perairan.

\section{Komunitas ikan terpenting}

Komunitas ikan terpenting pada perairan Tanimbar Utara (Tabel 3), yang mempunyai kepadatan total tertinggi adalah Pranesus pinguis sebanyak 653 ekor $(23,6 \%)$ dengan frekuensi kehadiran $71,4 \%$. Urutan kedua didominasi oleh jenis $S$. canaliculatus sebanyak 227 ekor $(8,2 \%)$ dengan frekuensi kehadiran 100\%, diikuti oleh Gerres oyena dan Scolopsis bilineatus masing-masing sebanyak 186 ekor $(6,7 \%)$ dengan frekuensi kehadiran

$71,4 \%$ dan $100 \%$. Pergeseran kedudukan antara $P$. pinguis dan $S$. canaliculatus disebabkan oleh frekuensi kejadian dan kelimpahan individu dari kedua jenis ikan tersebut, demikian pula halnya dengan jenis ikan lainnya. Kejadian seperti itu sudah pernah dijelaskan oleh Liyod and Ghelardi (1964, cis Genisa, 1991) dan Hutomo (1985)

Komunitas ikan terpenting dalam komunitas pada perairan pantai Teluk Saleh (Tabel 4) adalah Scolopsis ciliatus dari suku Nemipteridae dengan frekuensi kejadian $60 \%$.

Peringkat kedua diduduki oleh Sardinella lemuru dari suku Clupeidae dengan frekuensi $100 \%$ dan peringkat ketiga diduduki oleh Parupenaeus barberinus dari suku Mullidae dengan frekuensi kejadian $40 \%$. Hal ini disebabkan frekuensi kejadian dan kelimpahan individu dari setiap jenis.yang tertangkap selama penelitian berbeda.
Hasil penelitian menunjukkan bahwa terdapat jenis ikan yang bernilai ekonomis tinggi dan berpotensi untuk dibudidaya di teluk Saleh, seperti suku Siganidae, Chanidae, Serranidae, Lutjanidae, Lethrinidae, Mugilidae dan Caesionidae. Selain ikan, rumput laut dan mutiara juga sedang sedang dibudidaya saat ini di Teluk Saleh. Di lain pihak belum ada upaya budidaya hasil laut di perairan pantai Tanimbar Utara yang masih mengandalkan penangkapan dari alam.

Jika dibandingkan dengan hasil penelitian terdahulu, hasil penelitian ini sedikit berbeda. Hutomo (1985) misalnya, melaporkan jenis ikan paling dominan di Teluk Banten adalah Gerres oyen, di Teluk Grenyang adalah $S$. canaliculatus, di Teluk Tering adalah Gerres macrosoma (Genisa, 1990), di Padang Lamun adalah $P$. pinguis Setyono et al. (1991).

Genisa (1990) hanya menemukan 1445 individu yang mewakili 44 jenis dengan 30 suku di perairan Teluk Tering, Pulau Batam. Dari jumlah tersebut menunjukkan bahwa komposisi jenis maupun jumlah individu masih jauh lebih kecil dibandingkan dengan yang diperoleh di perairan Kecamatan Tanimbar Utara, tetapi jika dibandingkan dengan yang dilaporkan oleh Hutomo dan Djamali (1980) komunitas ikan di Padang Lamun lebih rendah, yaitu 76 jenis yang mewakili 32 suku. Secara keseluruhan pada penelitian ini menunjukkan bahwa komunitas ikan di perairan Teluk Saleh yang jauh lebih besar di bandingkan dengan perairan lain yang tersebut di atas. 
Tabel 3. Frekuensi jenis contoh ikan, kepadatan relatif atau tingkat dan nilai indeks Biologi (IB) kepadatan total (tingkat dan jumlah) dalam komunitas ikan di perairan Tanimbar Utara.

\begin{tabular}{|c|c|c|c|c|c|}
\hline \multirow{2}{*}{ Jenis Ikan } & \multirow{2}{*}{ Frekuensi kejadian (\%) } & \multicolumn{2}{|c|}{ Kepadatan relatif } & \multicolumn{2}{|c|}{ Kepadatan total } \\
\hline & & Tingkat & Nilai (IB) & Tingkat & Jumlah \\
\hline Gerres macrosoma & 28,6 & 1 & 4 & 17 & 37 \\
\hline G. oyena & 85,7 & 2 & 16 & 3 & 186 \\
\hline Halichoeres argus & 28,6 & 3 & 6 & 8 & 105 \\
\hline Scapularis & 42,9 & 4 & 1 & 20 & 22 \\
\hline Stechojulis strigiventer & 28,6 & 5 & 3 & 12 & 48 \\
\hline Siganus canaliculatus & 100 & 6 & 12 & 2 & 227 \\
\hline S. vermiculatus & 100 & 7 & 9 & 6 & 122 \\
\hline S.guttatus & 100 & 8 & 5 & 7 & 106 \\
\hline Stolephouss indicus & 28,6 & 9 & 2 & 19 & 23 \\
\hline Pranesus pinguis & 71,4 & 10 & 13 & 1 & 653 \\
\hline Pranesus spp. & 42,9 & 11 & 8 & 5 & 124 \\
\hline Lutjjanus russelli & 85,7 & 12 & 2 & 11 & 73 \\
\hline Lethrinus nebulosus & 71,4 & 13 & 2 & 9 & 92 \\
\hline L. olivaceus & 100 & 14 & 1 & 13 & 46 \\
\hline L. harak & 85,7 & 15 & 2 & 15 & 42 \\
\hline Lethrinus spp. & 100 & 16 & 1 & 18 & 36 \\
\hline Scolopsis bilineatus & 100 & 17 & 13 & 4 & 186 \\
\hline Aeoliscus strigatus & 42,9 & 18 & 4 & 16 & 39 \\
\hline Apogon leptacanthus & 28,6 & 19 & 4 & 10 & 82 \\
\hline Stenogobius suluensis & 28,6 & 20 & 1 & 21 & 22 \\
\hline Pentapodus trivittatus & 57,1 & 21 & 1 & 14 & 43 \\
\hline
\end{tabular}

Tabel 4. Frekuensi jenis contoh ikan (F), indek biologi (IB), tingkat (T) dan kelimpahan individu (K) jenis terpenting dalam komunitas ikan di perairan Teluk Saleh.

\begin{tabular}{|c|c|c|c|c|c|}
\hline \multirow{2}{*}{ Jenis Ikan } & \multirow{2}{*}{ Frekuensi kejadian (\%) } & \multicolumn{2}{|c|}{ Kepadatan relatif } & \multicolumn{2}{|c|}{ Kepadatan total } \\
\hline & & Tingkat & nilai (IB) & Tin & Jumlah \\
\hline Auxis rocheii & 2 & 1 & 1 & 14 & 4 \\
\hline Sardinella lemuru & 4 & 2 & 19 & 1 & 91 \\
\hline Sardinella spp & 2 & 3 & 2 & 9 & 7 \\
\hline Stolephorus waitei & 2 & 4 & 3 & 10 & 7 \\
\hline Thryssa baelama & 2 & 5 & 2 & 11 & 6 \\
\hline Carangoides uii & 3 & 6 & 4 & 4 & 21 \\
\hline Atule mate & 3 & 7 & 1 & 5 & 12 \\
\hline Lutjanus vitta & 2 & 8 & 1 & 12 & 6 \\
\hline Lethrinus spp & 3 & 9 & 1 & 7 & 9 \\
\hline Gerres spp & 3 & 10 & 4 & 8 & 9 \\
\hline Upeneus sulphureus & 2 & 11 & 7 & 6 & 10 \\
\hline Therapon jarbua & 2 & 12 & 1 & 13 & 6 \\
\hline Nemipterus virgatus & 4 & 13 & 11 & 2 & 38 \\
\hline N. mesoprion & 3 & 14 & 3 & 3 & 22 \\
\hline
\end{tabular}




\section{Kesimpulan dan Saran}

Dari hasil penelitian ini dapat disimpulkan bahwa komposisi jenis ikan diperairan Teluk Saleh, NTB lebih tinggi dibandingkan dengan di perairan Tanimbar Utara, Maluku Tenggara. Sedangkan jenis ikan terpenting dalam komunitas sebagaian besar berbeda, baik jumlah jenis maupun individu. Perlu dilakukan lebih lanjut pada kedua perairan tersebut baik menyangkut biodiversitas, musim, aspek biologi maupun kualitas lingkungan perairan yang mendukung budidaya ikan di masa mendatang.

\section{Ucapan Terima Kasih}

Penulis mengucapkan terima kasih kepada semua teknisi, staf, karyawan dan warga masyarakat yang terlibat langsung maupun secara tidak langsung dalam pengunpulan data di lapangan dan penyelesaian administrasi sehingga tulisan ini dapat diselesaikan. Namun penulis sangat menyadari sepenuhnya karena masih banyaknya kekurangan di sana sini sehingga kritik dan saran menjadi harapan untuk perbaikan di masa mendatang.

\section{Daftar Pustaka}

Allen, G. R. and Talbot, F. H., 1985. Indo-Pacific Fishes. Riview of the Snappers of the Genus Lutjanus (Pisces: Lutjanidae) from the IndoPacific, with Description of New Species. Bernice Pauhii Bishop Honolulu, Hawai.

Ayodhyoa, A. U., 1981. Metode Penangkapan Ikan. Seri Perikanan. Penerbit Yayasan Dewi Sri, Bogor.

Genisa, A. S., 1990. Komunitas Ikan di Perairan Teluk Teluk Tering, Pulau Batam. Oseanologi di Indonesia 23: 25 - 40.

Genisa, A. S., 1991. Komunitas Ikan di Muara Sungai Bengawan Solo, Jawa Timur. Prosiding, Seminar Ilmiah dan Kongres Nasional Biologi X, Bogor.
Hutomo, M. dan Martosewojo, S., 1977. The Fishes of Seagrass Cummunity on the West Side of Burung Island (Pari island, Seribu Island) and Their Variations in Abundance. Mar. Res. Indonesia 17: 147 - 172.

Hutomo, M., 1978. Ikan-Ikan di Muara Sungai karang : Suatu Analisis Pendahuluan tentang Kepadatan dan Struktur Komunitas. Oseanologi di Indonesia 9: 13 - 28.

Hutomo, M., 1985. Telaah Ekologi Komunitas Ikan Padang lamun (Seagrass, Anthophyta) di Perairan Teluk Banten. Thesis Fakultas Pascasarjana IPB, Bogor.

Hutomo, M. dan Djamali, 1980. Komunitas Ikan Padang Lamun "Seagrass" di Pantai Selatan Pulau Tengah, Gusus Pulau Pari. Sumberdaya Hayati Perairan. (Burhanuddin, M. K. Moosa dan H. Razak eds.) LON-LIPI, Jakarta.

Kuiter, H. R., 1992. Tropical Reef-Fishes of the Waters Pasific Groupers (Perciformes: Serranidae, Epinephelinae). PT Gramedia Pustaka Utama, Jakarta.

Langkosono, 1991. Beberapa Aspek Biologi Ikan Samandar (Siganis canaliculatus) di Perairan Teluk Un Kei Kecil. Dalam Perairan Maluku Tenggara. Balitbang SDL-P3O-LIPI. Ambon., 29 - 33.

Langkosono dan Wenno, L.F., 2000. Jenis-jenis Ikan Kerapu (Serranidae) yang Tertangkap dengan Pancing Tangan (vertical handline). Naskah Seminar Nasional Pendayagunaan Sumberdaya Hayati Dalam Pengelolaan Lingkungan. Salatiga. 3 Juni 2000.

Llyod, M., 1964. A. Table from Calculation the Equibility Component of Species Diversity. Journ. Anim. Ecol., 33: 217 - 225.

Munro, I. S. R., 1967. The Fishes of New Guinea Department of Agriculture of Stock Fish, Port Moresby. 650 pp.

Odum, E. P., 1971. Fundamental of Ecology. W. B. Saunders, Philadelphia: 574 pp.

Oviat, C. A. and Nixon S. W., 1973. The Demersalfish Naraganset Bay an Analysis of community Structure Distribution and Abundance. East. Coast. Mar. Sci. 1: 361 378. 
Pielow, I. C., 1976. The Measurement of Diversity in Different Types of Biological Collections. Journ. Biol. 13: 131 - 144.

Randall, J. E., 1965. Grazing Effect on Seagrass by Herbivorousreef Fishes in the West India Ecology 46: 225 - 260.

Randall, J. E. and Heemstra, P. C., 1991. Revision of Indo-Pacific Groupers (Perciformes: Serranidae, Epinephelinae) With the Description of Five New Species. IndoPacific Fishes. Benice Pauhi, Bishop Honolulu Hawai.

Rencana Strategis Pengelolaan Pesisir dan Laut. Coastal and Marine management Strategic Plan, 1998. Badan Perencanaan Pembangunan Daerah Propinsi Nusa Tenggara Barat.
Richards, S. W., 1963. The Demersal Fish Population of Long Island. Bul. Bingham Ocean, Coll. 18 (2): 5 - 101.

Setyono, D. E. D., Wouthuyzen, S. dan Peristiwady, T., 1991. Komunitas Ikan di Daerah Padang Lamun dan Terumbu Karang di Perairan Tanimbar, Maluku Tenggara. Dalam: Maluku Tenggara, Balitbang SDL, Puslitbang Oseanologi - LIPI, Ambon. 17 27.

Sato, S. 1978. A Synopsis of the Sporoid Fish the Genus Lethrinus, With Description of a new Species. The University Museum of Tokyo, Bulletin. 15.

Weber, M. and De Beaufort, L. F., 1936. The Fishes of the Indo-Australian Archipelago, 7. E. J. Brill, Leiden. 